ВЕСТНИК ПНИПУ. ГЕОЛОГИЯ. НЕФТЕГАЗОВОЕ И ГОРНОЕ ДЕЛО

BULLETIN OF PNRPU. GEOLOGY. OIL \& GAS ENGINEERING \& MININ

ISSN 2224-9923

Tom/Volume 15 №20 2016

http://vestnik.pstu.ru/geo/

УДК 553.98.061.4.

Article / Статья

(C) PNRPU / ПНИПУ, 2016

\title{
FEATURES OF STUDY COMPLEX CARBONATE RESERVOIR ROCKS` WETTING USING LABORATORY METHODS
}

\author{
I.P. Gurbatova, S.V. Melekhin, D.B. Chizhov, lu.V. Fairuzova
}

PermNIPIneft branch of LUKOIL-Engineering LLC in Perm (29 Sovetskoi Armii st., Perm, 614000, Russian Federation)

\section{ОСОБЕННОСТИ ИЗУЧЕНИЯ СМАЧИВАЕМОСТИ СЛОЖНОПОСТРОЕННЫХ КАРБОНАТНЫХ ПОРОД-КОЛЛЕКТОРОВ ЛАБОРАТОРНЫМИ МЕТОДАМИ}

\section{И.П. Гурбатова, С.В. Мелехин, Д.Б. Чижов, Ю.В. Файрузова}

Филиал ООО «ЛУКОЙЛ-Инжиниринг» ПермНИПИнефть в г. Перми (614000, Россия, г. Пермь, ул. Советской Армии, 29)

Received / Получена: 14.12.2015. Accepted / Принята: 29.08.2016. Published / Опубликована: 30.09.2016

Key words:

wettability, Amott method, carbonate reservoir, surface properties, industry standard, complex reservoirs, extraction, selective wettability.

Ключевые слова: смачиваемость, метод Амотта, карбонатный коллектор, поверхностные свойства, отраслевой стандарт, сложнопостроенный коллектор, экстракция, избирательная смачиваемость.

\begin{abstract}
Surface properties of rocks are the important parameter and have a great influence on the process of oil displacement by water. In real systems the wettability can range from highly hydrophilic to strongly hydrophobic depending on interaction between mineralized water and oil with rock surfaces. If the preferential wettability of any of two liquids is not observed in the rock, then the system has a neutral wetting. Some components of oil can wet the selected areas of porous surface around the reservoir. Under election wettability a spotted heterogeneous wettability of rock surface is understood. Wetting characteristic is a necessary criterion for evaluating the reservoir. There are qualitative and quantitative methods for estimating the wettability, which are divided into direct and indirect. Paper presents results of the study the surface properties of carbonate deposits, characterized by a complex structure of the hollow space and the complex composition of the mineral skeleton. Determination of wettability was carried out by two methods: according to industrial standard and Amott method. Characteristics of the rocks surface properties of different lithological types were established. To study the influence of extraction on the surface properties the wettability index was measured twice: in samples with natural oil saturation and in extracted samples. The regularities of changes in the surface properties along the well section of carbonate deposits were determined, a comparison of the wettability index and reservoir rock properties, as well as the residual water was performed by capillary pressure method. The descriptiveness analysis of various methods for determining the wettability was conducted and difference causes in the results of research were determind by methods of industrial standard and Amott. The presence of deposits, characterized by selective wetting was found.
\end{abstract}

Поверхностные свойства горных пород являются важным параметром, оказывающим большое влияние на процессы вытеснения нефти водой. В реальных системах смачиваемость может находиться в диапазоне от сильно гидрофильной до сильно гидрофобной в зависимости от взаимодействия минерализованной воды и нефти с поверхностью породы. Если в породе не наблюдается преимущественной смачиваемости какой-либо из двух жидкостей, то говорят, что система имеет нейтральную смачиваемость. Некоторые компоненты нефти могут смачивать избранные участки поровой поверхности породы по всему пласту. Под избирательной смачиваемостью понимают пятнистую неоднородную смачиваемость поверхности породы. Характеристика смачиваемости является необходимым критерием оценки коллектора. Существуют качественные и количественные методы оценки показателя смачиваемости, последние в свою очередь делятся на прямые и косвенные. В работе представлены результаты изучения поверхностных свойств карбонатных отложений, характеризующихся сложной структурой пустотного пространства и сложным составом минерального скелета. Определение показателя смачиваемости было выполнено двумя методами: по ОСТ и по методу Амотта. Установлены характеристики поверхностных свойств пород различного литологического типа. Для изучения влияния экстракции на поверхностные свойства показатель смачиваемости определяли дважды: у образцов с естественным нефтенасыщением и у экстрагированных образцов. Установлены закономерности изменения поверхностных свойств по разрезу скважин карбонатных отложений, выполнено сопоставление показателя смачиваемости и фильтрационно-емкостных свойств пород, а также остаточной водонасыщенности по методу капилляриметрии. Проведен анализ информативности различных методов определения смачиваемости и выявлены причины различий в результатах исследований по методам ОСТ и Амотта. Установлено наличие отложений, характеризующихся избирательной смачиваемостью.

Irina P. Gurbatova (Author ID in Scopus: 55536701100) - PhD in Engineering, Deputy Head of the Center of Core and Reservoir Fluids Analysis (tel.: +007 3427170 125, e-mail: IrinaGurbatova@pnn.lukoil.com).

Sergei V. Melekhin (Author ID in Scopus: 56979229100) - Head of the Department of Physic and Hydrodynamic Studies (tel.: +007 3427170 125, e-mail: Sergej.Melehin@pnn.lukoil.com).

Denis B. Chizhov (Author ID in Scopus: 57112213900) - Head of the Laboratory of Physic and Hydrodynamic Studies (tel.: +007 3427170 125, e-mail: Denis.Chizhov@pnn.lukoil.com).

Iuliia V. Fairuzova - Engineer of 2nd category of the Department of Physic and Hydrodynamic Studies (tel.: +007 342 71 70 125, e-mail: Yulija.Fairuzova@pnn.lukoil.com). The contact person for correspondence.

Гурбатова Ирина Павловна - кандидат технических наук, заместитель начальника центра исследований керна и пластовых флюидов (тел.: +0073427170125 , e-mail: IrinaGurbatova@pnn.lukoil.com).

Мелехин Сергей Викторович - начальник отдела физико-гидродинамических исследований (тел.: +007 34271 70 125, e-mail: Sergej.Melehin@pnn.lukoil.com). Чижов Денис Борисович - заведующий лабораторией физико-гидродинамических исследований (тел.: +007 342 71 70 125, e-mail: Denis.Chizhov@pnn.lukoil.com). Файрузова Юлия Владимировна - инженер 2-й категории отдела физико-гидродинамических исследований (тел.: +007 3427170 125, е-таil: Yulija.Fairuzova@pnn.lukoil.com). Контактное лицо для переписки. 


\section{Introduction}

Rock surface properties are an important parameter with a massive impact on water-oil displacement $[1,2]$.

In real systems wettability can range from highly hydrophilic to highly hydrophobic depending on the interaction of mineralized water and oil with rock surface $[3,4]$. If the rock manifests no prevalent wettability by any of the two fluids, it is referred to as having neutral wettability. Some oil components can wet selected parts of porous rock surface throughout the horizon. Selective wettability is understood as sporadic, inhomogeneous wettability of rock surface [5, 6].

Wettability of reservoir rocks by saturating phases is one of their main properties, since phase distribution in pore volume is a function of wettability $[7,8]$.

Therefore, wettability is a necessary criterion for reservoir assessment $[9,10]$.

Qualitative description of wettability and the targeted object can be received via capillary pressure curves, capillary intake, relative permeability curves, nuclear magnetic resonance method etc. [11, 12].

Quantitative methods of wettability assessment can be direct or indirect.

Direct methods of wettability assessment are based on meticulous measurement of interfacial wetting angles. However, if on a smooth surface the interfacial angle is fixed, then rough heterogeneous surface of natural rock creates conditions for a widely variable interfacial wetting angle. Due to the roughness of rock surface, a wide range of metastable drop conditions with different angles emerge [11].

Indirect methods imply assessment of rock wettability by designated indicators. Amott's method is based on measurement of fluid quantity imbibed by a sample at various conditions; United States Bureau of Mines (USBM) method is based on analysis of areas limited by capillary pressure curves received by sample centrifuging methods; combined Amott-USBM method also exists [5, 13].

Russian researchers most often use capillary intake method and forced displacement method under OST (Industry Standard) 39-180-85 [14].

Prior to the laboratory tests, drill sample is extracted in order to clean the pore volume from oil, bitumen, water and salts. Industry standard for calculation of wettability indicator simultaneously establishes the procedure for extracted drill samples testing.

In the course of physical and hydrodynamic drill samples analysis (water-oil displacement method, relative phase permeability) it is important to preserve surface rock properties corresponding to the natural condition in situ.

If due to the hot extraction a significant change occurred, the surface properties have to be recovered by means of drill sample "aging".

The objective of the research was to study the influence of extraction on the surface properties of complex carbonate reservoir deposits and analysis of usefulness of various wettability detection methods. Wettability was calculated using two most common methods: OST and Amott's.

\section{Wettability calculation using OST 39-180-85 and Amott's method}

OST method suggests determination of parameter expressing an integral feature of rock wettability based on capillary intake into the water and kerosene sample at atmospheric conditions and in gravity field during centrifuging.

Amott's method is also based on spontaneous intake of fluid by drill sample and forced extraction of oil and water from it. The test starts at residual oil saturation. Therefore, prior to the test it is required to create residual oil saturation in the sample by means of forced displacement of oil by water. Amott's wettability indicator $I_{w}$ is expressed as a relative parameter: water volumes ratio displaced by oil is deducted from oil volumes ratio displaced by water.

Wettability indicator is determined by result of capillary intake and forced displacement of water by kerosene during centrifuging.

The obtained wettability parameter is in the range between 0 and 1.0 under OST 39-180-85 and from 1.0 to1.0 under Amott's method (Table 1).

The research is performed for Upper Devonian carbonate deposits of one of the Timan-Pechora province fields. The results of petrophysical properties and wettability indicator study are shown in Figure 1.

Reservoir properties of the studied formation are very diverse: along with highly porous and cavernous rock, the sequence includes low porosity and fractured varieties.

Porosity and permeability study has been conducted for standard size and whole core drill samples. 
Table 1

Surface type and wettability indicator range

\begin{tabular}{|c|l|}
\hline Wettability indicator range $M$ & \multicolumn{1}{c|}{ Rock type } \\
\hline \multicolumn{2}{|c|}{ Under OST 39-180-85 } \\
\hline $0.0 \ldots 0.2$ & Hydrophobic \\
\hline $0.2 \ldots 0.4$ & Mainly hydrophobic \\
\hline $0.4 \ldots 0.6$ & Intermediate wettability \\
\hline $0.6 \ldots 0.8$ & Mainly hydrophilic \\
\hline $0.8 \ldots 1.0$ & Hydrophilic \\
\hline \multicolumn{2}{|c|}{ Under Ammot's method } \\
\hline$-1.0 \ldots-0.6$ & Hydrophobic \\
\hline$-0.6 \ldots-0.2$ & Mainly hydrophobic \\
\hline$-0.2 \ldots 0.2$ & Intermediate wettability \\
\hline $0.2 \ldots 0.4$ & Mainly hydrophilic \\
\hline $0.4 \ldots 1.0$ & Hydrophilic \\
\hline
\end{tabular}

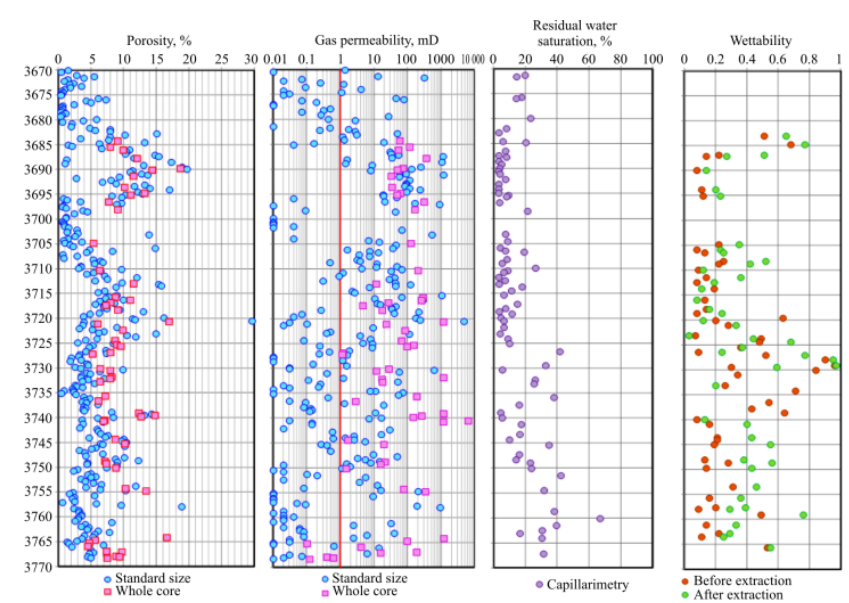

Figure 1. Variability of porosity and permeability, residual water saturation and wettability of rocks in depth

Overall, the deposits in the studied sequence can be referred to as multicapacity complex type reservoir, containing an alternation of the following types of reservoirs: porous, fractured-porous, porous-fractured and porous-cavernous complicated by fracturing.

Rock wettability indicator was determined twice: in the samples with natural saturation (before extraction) and in the extracted samples. Express inhomogeneity of wettability in depth can be described as heterogeneous (selective).

Overall, the inner rock surface consists of a variety of minerals with diverse surface chemical and adsorption properties that can result in variable wettability.

In case of selective (heterogeneous) wettability, oil components are intensely adsorbed by selective rock areas, so that part of the rock is highly hydrophobic and the other part of highly hydrophilic [5].

Drawing on the results of lithologic and petrographic study it was established that carbonate formation of this age developed in conditions of shallow marine shelf.

The sequence contains microbial limestones with lumped granular microstructure, areas of intraclasts and fenestral cavities. Rocks are stylolitized, dolomitized, sulfated, oil- and gas-saturated. Their color is light grey, grey, in oil saturated areas - dark brown. Rocks are porous, cavernous-porous, sporadically fractured. Limestones are highly dolomitized, sporadically transitioning to secondary replacement dolomites.

Table 2 summarized lithological types of rock based on the results of microscopic research.

\section{Table 2}

Wettability parameter by lithological types of rock

\begin{tabular}{|l|c|c|c|c|}
\hline \multirow{2}{*}{ Lithological type } & Drill sample & \multicolumn{3}{|c|}{ Wettability values } \\
\cline { 3 - 5 } & extraction & minimum & maximum & mean \\
\hline \multirow{2}{*}{$\begin{array}{l}\text { Microbial } \\
\text { limestone }\end{array}$} & Before & 0.07 & 0.90 & 0.31 \\
\hline $\begin{array}{l}\text { Microbial } \\
\text { dolomitous and } \\
\text { dolomitic } \\
\text { limestone }\end{array}$ & Before & 0.03 & 0.95 & 0.42 \\
\cline { 2 - 5 } & After & 0.11 & 0.96 & 0.31 \\
\hline $\begin{array}{l}\text { Secondary } \\
\text { dolomite for } \\
\text { microbial } \\
\text { limestone }\end{array}$ & Before & 0.08 & 0.87 & 0.43 \\
\cline { 2 - 5 } & After & 0.08 & 0.68 & 0.27 \\
\hline
\end{tabular}

Figure 2 shows photographs of sections. Figure 2, $a$ displays microbial limestone with calcium bionts, sulfated (10-12\%), oil saturated, porous $(\sim 5 \%)$. Intra- and interform leached pores, open, partially remedies by anhydrite and/or newly formed

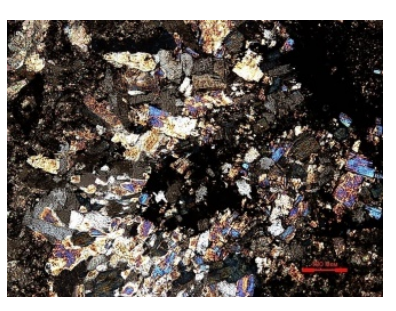

a

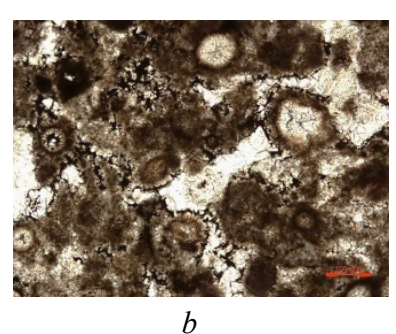

b
Figure 2. Section samples: $a-1 / 15$, D3zd. Sporadic sulfation (anhydritization) in microbial limestone. With analyzer; $b-1 / 9$, D3zd. Microbial limestone. Black oxidized bitumen fills fine intercrystalline and interform pores. Without analyzer

calcite. Pores are isolated or connected. Authigenous: anhydrite crystals are scattered across the rock, partially fill the pores, or concentrate in form of rounded spots.

Figure $2, b$ shows microbial limestone with calcium bionts, porous-cavernous (up to $10 \%$ ), saturated with 
black heavy oxidized bitumen which partially or fully fills the pores and caverns, determining the rock structure. Leached pores and caverns are inter- and intrafirm. Their shape is elongated, isometric, mostly irregular. Cavities are connected or isolated. Their size reaches $2.75 \mathrm{~mm}$. Authigenous: anhydrite (occasional).

Figure 3 shows a comparison between wettability indicator before and after extraction depending on the lithological type of rock.

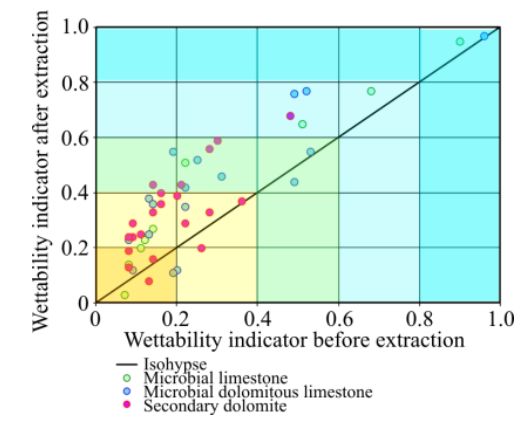

Figure 3. Wettability indicator comparison before and after extraction

The experiment results indicate that after extraction hydrophilic properties of the rock improve; nevertheless, extraction does not lead to the complete metamorphosis of hydrophobic rocks to hydrophilic.
As seen from the chart, part of the samples has moved to the area of mainly hydrophobic and intermediate wettability, while part of the samples has retained their hydrophobic properties.

\section{Comparison of wettability calculation results}

Table 3 presents the results of wettability indicator calculation by Amott's method and OST in the samples with natural saturation (before extraction) and extracted samples.

Figure 4 shows the results of comparison between OST 39-180-85 and Amott's method results depending on the samples depth of occurrence.

As per the Industry Standard, rock surface properties are characterized by hydrophobic and partially neutral and hydrophilic wettability in samples with natural saturation and extracted samples.

Per Amott's method, surface properties are characterized by neutral and partially hydrophobic and hydrophilic wettability in samples with natural saturation; in extracted samples - by neutral and hydrophilic wettability.

Table 3

Wettability indicator calculation results obtained by Amott's method and OST 39-180-85

\begin{tabular}{|c|c|c|c|c|c|c|c|c|c|c|c|c|}
\hline \multirow{2}{*}{ Sr. No. } & \multirow{2}{*}{$\begin{array}{l}K_{\mathrm{pg}} \\
\mathrm{mD}\end{array}$} & \multirow{2}{*}{$K_{\mathrm{p}}, \%$} & \multirow{2}{*}{ Depth, m } & \multicolumn{2}{|c|}{$\begin{array}{c}\text { Displaced water } \\
\text { volume }\end{array}$} & \multirow{2}{*}{$\begin{array}{l}\text { Wettabili- } \\
\text { ty by } \\
\text { kerosene }\end{array}$} & \multicolumn{2}{|c|}{$\begin{array}{c}\text { Displaced kerosene } \\
\text { volume }\end{array}$} & \multirow{2}{*}{$\begin{array}{c}\text { Wettabili- } \\
\text { ty by } \\
\text { water } \\
\text { under OST }\end{array}$} & \multirow{2}{*}{$\begin{array}{c}\text { Surface } \\
\text { nature by } \\
\text { OST }\end{array}$} & \multirow{2}{*}{$\begin{array}{c}\text { Amott's } \\
\text { wettabi- } \\
\text { lity }\end{array}$} & \multirow{2}{*}{$\begin{array}{l}\text { Surface } \\
\text { nature by } \\
\text { Amott }\end{array}$} \\
\hline & & & & $\begin{array}{c}\text { Capillary } \\
\text { intake }\end{array}$ & $\begin{array}{l}\text { Centrifu- } \\
\text { ging }\end{array}$ & & $\begin{array}{c}\text { Capillary } \\
\text { intake }\end{array}$ & $\begin{array}{c}\text { Centrifu } \\
\text {-ging }\end{array}$ & & & & \\
\hline 21-51-14 & 31.80 & 10.27 & 36 & 0.089 & 1.635 & & 0.485 & 0.950 & 0.511 & & 0.457 & pr.h \\
\hline $21-147-14$ & 210.70 & 13.00 & 3718.65 & 0.193 & 2.121 & 0.091 & 0.445 & 1.834 & 0.243 & pr.h/phob & 0.152 & neut. \\
\hline 21-177-14 & 10.01 & 2.01 & 3727.95 & 0.054 & 0.177 & & 0.176 & 0.185 & 0.951 & & 0.648 & $\mathrm{~h} /$ phil \\
\hline $21-270-14$ & 186.04 & 9.60 & 3757.63 & 0.178 & 1.417 & 0.126 & 0.468 & 1.210 & 0.387 & pr.h/phob & 0.261 & pr.h/phil \\
\hline
\end{tabular}

Note : $K_{\mathrm{pg}}$ - gas permeability factor; $K_{\mathrm{p}}$ - porosity factor; neut - neutral; pr.h/phob - predominantly hydrophobic; pr.h/phil predominantly hydrophilic; h/phil - hydrophilic.
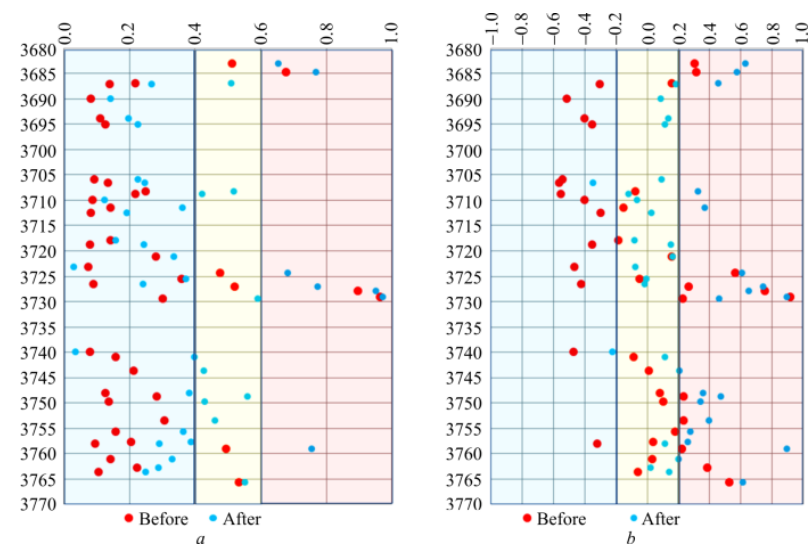

Figure 4. Research results obtained by OST 39-180-85 (a) and Amott's method (b)
The results are based on the fact that the Industry Standard takes into account only the volume of kerosene displaced by water, while Amott's method draws on the difference between volume of kerosene displaced by water and water displaced by kerosene.

Thus Amott's method appears to be more informative and objective. The method takes into account the volumes of displaced fluid at all stages of research.

This is especially evident in case of samples with selective wettability where finer pores are occupied with water and rock matrix is hydrophilic, while in larger pores it's hydrophobic, and continuous "fibers" of oil stretch across the 
entire core through these larger pores. In these samples oil displacement occurs even at extremely low oil saturation [1].

\section{Summary}

1. Carbonaceous rocks of the studied sequence possess complex structure of voids and complex composition of mineral matrix. The rocks are stylolithized, dolomitized, sulphated, oil-and gassaturated.

2. Surface properties of reservoir rocks of the studied sequence display high inhomogeneity.
Express wettability inhomogeneity in depth can be described as heterogeneous (selective) wettability.

3. Extraction produces partial hydrophiliainducing impact on surface rock properties, but does not lead to wettability change from hydrophobic to hydrophilic. Sample values remain within the limits of one group of surface properties or transfer to the adjacent one, which is an insignificant change.

4. Difference in wettability indicators defined by OST and Amott's method is common for samples with selective wettability.

\section{References}

1. Mikhailov N.N., Sechina L.S., Gurbatova I.P. Pokazateli smachivaemosti v poristoi srede i zavisimost' mezhdu nimi [Wettability indicators in the porous environment and dependence between them], available at: http://oilgasjournal.ru/vol_3/mikhailov-sechina.html

2. Kuznetsov A.M., Kuznetsov V.V., Bogdanovich N.N. O sokhranenii estestvennoi smachivaemosti otbiraemogo iz skvazhin kerna [On the question of preserving natural wettability of a core taken from wells]. Neftianoe khoziaistvo, 2011, no.1, pp.21-23.

3. Gaisin M.R., Folomeev A.E., Makatrov A.K., Telin A.G., Afanas'ev I.S., Fedorov A.I., Emchenko O.V., Zainulin A.V. Opredelenie smachivaemosti kerna mestorozhdenii Vala Gamburtseva razlichnymi metodami [The measurement of Val Gamburtzeva oil field core's wettability by different methods]. Territoriia neftegaz, 2011, no.4, pp.46-52.

4. Buckley J.S., Liu Yu, Xie Xina, Morrow N.R. Asphaltenes and crude oil wetting - the effect of oil composition. SPE Journal, 1997, vol.2, is.02, pp.107-119. DOI: $10.2118 / 35366-P A$.

5. Tiab Dzh., Donaldson Erl Ch. Petrofizika: teoriia i praktika izucheniia kollektorskikh svoistv gornykh porod i dvizheniia plastovykh fliuidov [Petrophysics: theory and practice of measuring reservoir rock and fluid transport properties]: perevod s angliiskogo. Moscow: Premium-Inzhiniring, 2009, 868 p.

6. Jadhunandan P.P., Morrow N.R. Effect of wettability on waterflood recovery for crude-oil/brine/rock systems. SPE Reservoir Engineering, 1995, 10 (1), pp.4046. DOI: $10.2118 / 22597-P A$.

7. Amiks Dzh., Bass D., Uaiting R. Fizika neftianogo plasta [Physics of oil reservoir]. Moscow: Gostoptekhizdat, 1962, 572 p.

8. Zhou Xianmin, Morrow N.R., Ma Shouxiang. Interrelationship of wettability, initial water saturation, aging time, and oil recovery by spontaneous imbibitions and waterflooding. SPE Journal. 2000, vol.5, is.02, pp.199-207. DOI: 10.2118/62507-PA.

9. Mikhailov N.N., Sechina L.S., Gurbatova I.P. Pokazateli smachivaemosti v poristoi srede i zavisimost' mezhdu nimi [Microstructural wettability. Specifics of manifestations and influence on the reservoir filtration properties]. Miedzynarodowa Konferencja Naukowo-Techniczna Geopetrol. Krakow, 2012, pp.629-634.

10. Morrow N.R. Wettability and its effect on oil recovery. Journal of Petroleum Technology, 1990, 42 (12), pp.1476-1484. DOI: 10.2118/21621-PA.

11. Gudok N.S., Bogdanovich N.N., Martynov V.G. Opredelenie fizicheskikh svoistv neftesoderzhashchikh porod [Determination of the physical properties of oil-containing rocks]. Moscow: Nedra, 2007, $592 \mathrm{p}$.

12. Al-Yousef H.Y., Lichaa P.M., Al-Kaabi, Alpustun H. Wettability evaluatin of a carbonate reservoir rock from core to pore level. Middle East Oil Show, 1995, pp.11-14. DOI: 10.2118/29885-MS.

13. Tul'bovich B.I. Metody izucheniia porod-kollektorov nefti i gaza [Methods of study of oil and gas reservoir rocks]. Moscow: Nedra, 1979, $199 \mathrm{p}$.

14. OST 39-180-85. Neft'. Metod opredeleniia smachivaemosti uglevodorodosoderzhashchikh porod [Method for determining the wettability of hydrocarbon species], available at: http:// www. $1 \mathrm{bm} . \mathrm{ru} / \mathrm{techdocs} / \mathrm{kgs} /$ ost $/ 16 /$ info/34/.

15. Mikhailov N.N., Semenova N.A., Sechina L.S. Vliianie mikrostrukturnoi smachivaemosti na petrofizicheskie kharakteristiki porod-kollektorov [The influence of microstructure wetting on the petrophysical characteristics of the reservoir rocks]. Karotazhnik, 2011, no.7 (205), pp.163-172. 


\section{Список литературы}

1. Михайлов Н.Н., Сечина Л.С., Гурбатова И.П. Показатели смачиваемости в пористой среде и зависимость между ними [Электронный ресурс]. - URL: http://oilgasjournal.ru/vol_3/mikhailov-sechina.html (дата обращения: 18.04.2016).

2. Кузнецов А.М., Кузнецов В.В., Богданович Н.Н. О сохранении естественной смачиваемости отбираемого из скважин керна // Нефтяное хозяйство. - 2011. - № 1. C. 21-23.

3. Определение смачиваемости керна месторождений Вала Гамбурцева различными методами / М.Р. Гайсин, А.Е. Фоломеев, А.К. Макатров, А.Г. Телин, И.С. Афанасьев, А.И. Федоров, О.В. Емченко, А.В. Зайнулин // Территория нефтегаз. - 2011. - № 4. - С. 46-52.

4. Asphaltenes and crude oil wetting - the effect of oil composition / J.S. Buckley, Yu Liu, Xina Xie, N.R. Morrow // SPE Journal. - 1997. - Vol. 2, is. 02. P. 107-119. DOI: $10.2118 / 35366-P A$.

5. Тиаб Дж., Доналдсон Эрл Ч. Петрофизика: теория и практика изучения коллекторских свойств горных пород и движения пластовых флюидов: пер. с англ. - М.: Премиум-Инжиниринг, 2009. - 868 с.

6. Jadhunandan P.P., Morrow N.R. Effect of wettability on waterflood recovery for crude-oil/brine/rock systems // SPE Reservoir Engineering. - 1995. - 10 (1). P. 40-46. DOI: 10.2118/22597-PA.

7. Амикс Дж., Басс Д., Уайтинг Р. Физика нефтяного пласта. - М.: Гостоптехиздат, 1962. - 572 с.

8. Zhou Xianmin, Morrow N.R., Ma Shouxiang. Interrelationship of wettability, initial water saturation, aging time, and oil recovery by spontaneous imbibitions and waterflooding // SPE Journal. - 2000. - Vol. 5, is. 02. - P. 199-207. DOI: 10.2118/62507-PA.

9. Микроструктурная смачиваемость. Специфика проявления и влияния на фильтрационные свойства пласта / Н.Н. Михайлов, К.А. Моторова, В.А. Кузьмин, Н.Н. Семенова, Л.С. Сечина // Miedzynarodowa Konferencja Naukowo-Techniczna Geopetrol 2012 / Prace Naukowe INiG nr 182. Instytut Nafty i Gazu. - Krakow, 2012. - P. 629-634.

10. Morrow N.R. Wettability and its effect on oil recovery // Journal of Petroleum Technology. - 1990. 42 (12). - P. 1476-1484. DOI: 10.2118/21621-PA.

11. Гудок Н.С., Богданович Н.Н., Мартынов В.Г. Определение физических свойств нефтесодержащих пород. - М.: Недра, 2007. - 592 с.

12. Wettability evaluatin of a carbonate reservoir rock from core to pore level / H.Y. Al-Yousef, P.M. Lichaa, Al-Kaabi, H. Alpustun // Middle East Oil Show. - 1995. P. 11-14. DOI: 10.2118/29885-MS.

13. Тульбович Б.И. Методы изучения породколлекторов нефти и газа. - М.: Недра, 1979. - 199 с.

14. ОСТ 39-180-85. Нефть. Метод определения смачиваемости углеводородосодержащих пород [Электронный pecypc]. - URL:http://www.1bm.ru/ techdocs/kgs/ost/16/info/34/ (дата обращения: 12.04.2016).

15. Михайлов Н.Н., Семенова Н.А., Сечина Л.С. Влияние микроструктурной смачиваемости на петрофизические характеристики пород-коллекторов // Каротажник. - 2011. - № 7 (205). - С. 163-172.

Please cite this article in English as:

Gurbatova I.P., Melekhin S.V., Chizhov D.B., Fairuzova Iu.V. Features of study complex carbonate reservoir rocks` wetting using laboratory methods. Bulletin of PNRPU. Geology. Oil \& Gas Engineering \& Mining, 2016, vol.15, no.20, pp.240-245. DOI: $10.15593 / 2224-9923 / 2016.20 .4$

Просьба ссылаться на эту статью в русскоязычных источниках следующим образом:

Особенности изучения смачиваемости сложнопостроенных карбонатных пород-коллекторов лабораторными методами / И.П. Гурбатова, С.В. Мелехин, Д.Б. Чижов, Ю.В. Файрузова // Вестник Пермского национального исследовательского политехнического университета. Геология. Нефтегазовое и горное дело. - 2016. - Т.15, №20. - С.240-245. DOI: $10.15593 / 2224-9923 / 2016.20 .4$ 